\title{
The Doctrine of Piercing The Corporate VEIL: ITS LEGAL AND JUDICIAL RECOGNITION IN ETHIOPIA
}

\author{
Endalew Lijalem Enyew *
}

\begin{abstract}
:
Upon acquisition of legal personality a company enjoys certain attributes such as limited liability. While the separate legal personality of a company enables it to enjoy rights and assume obligations quite different from its members, the limited liability of shareholders refers to the fact that the company alone is liable for its debts. However, such privilege of limited liability may not always exist when the legal personality of a company is abused and used for illegitimate or unlawful purposes and other reasons. This article examines some of the grounds by which the corporate veil can be pierced under Ethiopian law and the role of courts in recognizing the doctrine. Based on the analysis of the relevant legislative provisions and some court cases, it is found that Ethiopian company law, though not sufficient, provides some clear grounds of piercing the corporate veil and certain possible grounds which may call for the application of the doctrine. It is also argued that Ethiopian courts should apply the doctrine of piercing the corporate veil, through the purposive interpretation of the statutory provisions, if doing so produces equitable results and fairness.
\end{abstract}

\section{Key Words:}

Company, corporate veil, piercing the veil, Ethiopia

DOI http://dx.doi.org/10.4314/mlr.v6i1.3

\section{Introduction}

The separate legal personality of a company renders it a juridical person distinct from its shareholders. The other attribute of a company is limited liability of share holders in which the company will alone be liable for the debts it incurs. That is, if the company becomes unable to pay its debts, the members of that

* LL.B (Hawassa University), LL.M (Addis Ababa University); and currently studying MPhil in Peace and Conflict Transformation, at Tromsø University, Norway. I would like to thank Zekarias Keneea (Associate professor) for his continuous and unreserved advice, and Elias N. Stebek (Assistant Professor) for his comments and corrections which constitutes the final version of this Article. Email:

$<$ netsuhfiker@gmail.com> or <lijendalew558@yahoo.com> 
company will not have to contribute towards paying the company's debts out of their private funds.

The attribute of limited liability of a company is known as the corporate veil or shell, due to the protection it offers to the shareholders by protecting or keeping them from the reach of outsiders (creditors). However, such privilege of limited liability may not always exist when, inter alia, the legal personality of a company is abused and used for illegitimate or unlawful purposes. If it is shown that the legal personality has been abused and used to the detriment of third parties (creditors), the theory of legal personality will be disregarded and it is looked upon as a collection of persons instead of a collection of capital. Consequently, the individual member(s), director(s) and manager(s) will be held liable for the wrongs caused through the use of the legal entity. This process is known as piercing or lifting the corporate veil.

Based on legislative analysis, interview, and case analysis, this article tries to explore some possible grounds by which the corporate veil can be pierced under Ethiopian law and the role of courts in recognizing and applying the doctrine. The first section of the article deals with the basic attributes of a company. The second section deals with the meaning and origin of the doctrine of piercing the corporate veil, followed by a discussion on the grounds for piercing the corporate veil in some foreign laws, both in the common and civil law legal systems. The fourth section explores some possible grounds of piercing the corporate veil under Ethiopian company law and the role of Ethiopian courts in this regard. Finally section five forwards conclusions.

\section{The Basic Attributes of a Company}

Gogna defines a company ${ }^{1}$ as "a voluntary association of persons formed to achieve some common objectives, having a separate legal entity, independent and separate from its members, with a perpetual succession and a common seal, and with capital divisible into transferable shares." Although Ethiopian law does not expressly define a company, it is possible to understand what a

${ }^{1}$ While the term 'Company' is used in the Ethiopian legal system, the term 'Corporation' is commonly used in the common law legal system though it is broader in concept which includes public enterprises. Since the doctrine of piercing the corporate veil is of common law origin, the term corporation is seldom used in this article particularly in sections dealing about foreign laws and not to confuse it with the term company. However, the term company is exclusively used in the sections dealing with the legal and judicial recognition of the doctrine in Ethiopia.

${ }^{2}$ Gogna, P.P.S (2004), A Textbook of Company Law (New Delhi: S. Chand \& Company Ltd.), p.9. 
company is through its major attributes, namely, separate legal personality and limited liability of shareholders $\backslash$ members.

\subsection{Separate legal personality}

When a company fulfils the requirements laid down for its formation, the law considers it as a person. That is, in the eyes of the law, it is a person capable of enjoying rights and assuming obligations quite different from the physical persons who brought it into existence or who may be its members at any given

time. ${ }^{3}$ The rights and obligations of the individual members are not those of the company and vice versa.

The decision of the House of Lords in the case of Salomon v. Salomon \& Co. Ltd [1897] which revised the decisions of the Higher Court and the Court of Appeal marks the beginning of the judicial acceptance of the company as a separate legal entity. The facts in Salomon V. a Salomon \& Co. Ltd are given below (as stated in Stephen Griffin, Company law: fundamental principles). ${ }^{4}$ The proprietor of a small but successful business, Mr. Salomon, formed a business as a limited company in accordance with the registration provisions contained within the Companies Act 1862. Section 6 of the Act provided that "seven or more persons together could form a business provided that it was associated for a lawful purpose." 5

The seven subscribers to the Salomon \& Co. Ltd were Mr. Salomon, his wife and their five children. The company, A Salomon \& Co. Ltd, purchased Mr. Salomon's business in a solvent state for a consideration to a value of approximately $£ 39,000$. Mr. Salomon received $£ 20,000$ a fully paid-up $£ 1$ shares, an issue of debentures to the value of $£ 10,000^{6}$. The remaining six members of Salomon's family were each allotted a $£ 1$ share in the company. ${ }^{7}$

Unfortunately, a Salomon \& Co. Ltd did not prosper. Mr. Salomon's debentures were transferred to Mr. Broderip in return for $£ 5000$; this amount was then pumped back to the company by Mr. Salomon. Despite further efforts on the part of Mr. Salomon to keep the company afloat, less than a year after its

${ }^{3}$ Seifu Teklemariam (1968), Piercing the corporate veil: its application to private limited companies and share companies in Ethiopia, Senior Thesis, Faculty of Law, Haile Selassie I University, (unpublished), p. 4.

${ }^{4}$ Griffin Stephen (2004), Company law: fundamental principles, (4 ${ }^{\text {th }}$ ed.), Pearson Longman, p. 6.

${ }^{5}$ Ibid, Salomon v A Salomon \& Co Ltd [1897] AC 22 (House of Lords).

${ }^{6}$ A debenture acknowledges a loan or other credit agreement between the company and its creditors and is normally secured against the assets of the company. In Salomon's case the debenture was secured by means of a floating charge and took the remainder of the sale price in cash.

${ }^{7}$ Griffin Stephen, supra note 6, p. 6. 
formation, the company fell into an insolvent state. ${ }^{8}$ The company could not meet Broderip's debenture interest payments and, fearful that his investment would be lost, Broderip sought to realize his security (the floating charge) by appointing a receiver. The company, which had other creditors, was subsequently put into liquidation. ${ }^{9}$ The liquidation (resulting, ultimately in a sale of corporate assets) of the company's assets realized sufficient funds to meet the company's debt to Broderip but not the debts owed to the company's other creditors who, unlike Brodrip, had no secured interest (debentures).

In the High court (heard as Broderip v. Salomon [1895] 2 Ch 322), the liquidator admitted the validity of Broderip's prior claim to be repaid from the company's assets because he had priority as holder of a secured loan. Nevertheless, the liquidator counter-claimed that the company and, therefore, the company's unsecured creditors were entitled to be reimbursed by $\mathrm{Mr}$. Salomon personally. ${ }^{10}$

The trial judge, Vaughan Williams $\mathrm{J}$, agreed with this contention. Whilst admitting that upon its registration a company is a legal entity, distinct from its shareholders, the learned judge opined that A Salomon \& Co. Ltd (the company) was no more than an agent of its principal, i.e. Mr. Salomon. As such, the principal was responsible for the debts of its agent. The basis for the agency argument was that a company was a mere alias of its founder and had not been formed in accordance with the true spirit of the 1862 companies Act. Vaughan Williams J believed that "the 1862 Act, in its requirement for 'seven persons associated for a lawful purpose' should be interpreted to mean seven persons with a bona fide intention of participating in a trading venture, and not, as in the present case, a company which, in reality, was akin to a one-man business."11

On appeal, the decision of Vaughan Williams J was upheld, although in the Court of Appeal's opinion the correct analogy between the company and Mr. Salomon was that of trust relationship: the company held its property on trust for its beneficiary, Mr. Salomon. As such, the creditors of A Salomon \& Co. Ltd were entitled to claim against Mr. Salomon through the company. As the High Court, the Court of Appeal recognized that A Salomon \& Co. Ltd, in complying with the registration provisions of the 1862 Act, had been validly formed as a separate legal entity. However, the court did not recognize that the liability of A Salomon \& Co. Ltd should be divorced from that of its founder, Mr. Salomon. The Court of Appeal agreed with the High Court that in relation to the requirements of formation, the correct interpretation of the Companies Act 1862

\footnotetext{
${ }^{8}$ Ibid.

${ }^{9}$ Ibid.

${ }^{10}$ Ibid, p. 7.

${ }^{11}$ Ibid.
} 
was that seven persons who become members of the company should participate in the venture, rather than having nominal and superficial interest. ${ }^{12}$

Notwithstanding that the business had been profitable prior to its formation, Lindley LJ (the Appellate Court's judge) was of the opinion that "the manner in which the company had been formed indicated that it had been created for an illegitimate purpose, that it was a device to defraud creditors and as such was therefore contrary to the terms of the Companies Act 1862" because it was not associated for lawful purpose. In the Court of Appeal's opinion the company's illegitimacy stemmed from the fact that it was in reality a one-man company. Lopes LJ Stated:

If we were to permit it to succeed, we should be authorizing a perversion of the joint Stock Companies Act. We should give vitality to that which is a myth and a fiction... To legalize such a transaction will be a scandal. ${ }^{13}$

The House of Lords revised the decision of the Court of Appeal which had held that a company could not be formed by one dominant character together with six other persons divorced of substantial interest in the business venture. According to the House, the statutory language of the Companies Act 1862 was clear. "A company could be formed provided it had at least seven members, irrespective of whether all seven members made a substantial contribution to the company.",14

Although both the High Court and the Appellate Court recognized that A Salomon \& Co. Ltd, having complied with the registration provisions of the 1862 Act, was a corporate entity, they had not contemplated the fact that once formed the company could not be considered as anything other than an independent entity, totally separate and distinct from its founder, Mr. Salomon. The House of Lords' interpretation of the separate legal identity of a company was, in respect of A Salomon \& Co. Ltd, absolute. Lord Macnaughten stated thus:

The company is at law a different person altogether from the subscribers to the memorandum; and though it may be that after formation the business is precisely the same as it was before, and the same persons are managers, and the same hands receive the profits, the company is not in law the agent of the subscribers or trustee for them. Nor are the subscribers as members liable, in any shape or form, except to the extent and in the manner provided by the act. ${ }^{15}$

\footnotetext{
${ }^{12}$ Ibid.

${ }^{13}$ Ibid. p. 8

${ }^{14}$ Ibid.

${ }^{15}$ Ibid.
} 
The House of Lords in considering the agency and trust arguments of the lower courts concluded that both were contradictory to the view that the company was a separate legal entity. The finding of the agency or trust relationship would have meant that Mr. Salomon would have been personally liable for the company's debt. Lord Halsbury remarked "once the company is legally formed it must be treated like any other independent person with rights and liabilities appropriate to itself, and that the motives of those who took part in the promotion of the company are absolutely irrelevant in discussing what those rights and liabilities are". ${ }^{16}$ It is this decision of the House of Lords that marked the beginning of the judicial acceptance of the company as a separate legal entity distinct from its members.

Under Ethiopian Commercial Law, legal personality is acquired by fulfilling the various requirements of the Commercial Code of Ethiopia and upon publication in an official commercial Gazette. ${ }^{17}$ However, the publication requirement did not practically exist as there is no commercial Gazette and recently the new registration and licensing proclamation (Proclamation No. 686/2010) has explicitly abrogated the requirement of publication.

Once a company acquires legal personality, there are important consequences attached to it. These include the company's name, nationality and place of residence, the right to possess and administer property, its right to enter into juridical acts in its name, sue and be sued, and the company's perpetual existence.

\subsection{Limited liability of shareholders/ members}

Limited liability of share holders/members is another basic attribute of a company which makes it the chosen mode of business. Since a company is a separate person with property interests, it will alone be liable for the debts it incurs. This means that, if the company becomes unable to pay its debts, the members of that company will not have to contribute towards paying the company's debts out of their private funds. The shareholders are liable only to the extent of the amount they have paid, or have promised to pay, for their shares. ${ }^{18}$ Share prices need not necessarily be paid when they are first purchased. When some money is outstanding on shares, the company may issue

\footnotetext{
${ }^{16}$ Ibid, p. 9

${ }^{17}$ Commercial Code of Ethiopia, 1960, (Negarit Gazetta, Proclamation No. 166/1960, Year 19, No. 3), Articles 223, 323, 324.

${ }^{18}$ Dine Janet and Koutsias Marios (2007), Company Law, (6 ${ }^{\text {th }}$ ed.), London: Palgrave Macmilan, p.2.
} 
a 'call' for the remainder to be paid, but it can never demand more than the full price due to the company for that share. ${ }^{19}$

Hence, a company is responsible for its own actions and will be predominantly liable for its own debts and the company's creditors cannot seek the satisfaction of their claims from the members even if the company's funds (assets) are insufficient to pay its liabilities in full. Moreover, the personal creditors of shareholders have no right to the company's assets except to the extent of the debtor member's share. ${ }^{20}$ However, it must be noted that the law does not prevent the companies from making the liability of its members unlimited through the express provisions in the articles of association. ${ }^{21}$

The rule of limited liability has a general application. It applies to all companies regardless of the number of shareholders, the type of business, or even whether they have business operations at all or merely function as a shareholding parent within a corporate group. ${ }^{22}$ Share companies and private limited companies differ from other forms of business organizations in that the latter do not enjoy limited liability except those who are limited partners in limited partnerships. ${ }^{23}$ This attribute of a company has greatly facilitated the expansion of business, particularly in the risky ventures. This is because limited liability encourages greater risk-taking in the business community, so that new avenues of commerce are explored, and this enhances employment

${ }^{19}$ Ibid, p. 12.

${ }^{20}$ Chon E. J and Simitis C. (1963) 'Lifting the veil in the company laws of the European continent', International and Comparative Law Quarterly, Vol. 12, No. 1, Cambridge University press, p.189.

${ }^{21}$ Bagrial Ashok K. (2007), Company Law, (12 ${ }^{\text {th }}$ revised ed.), New York: Vikas Publishing House Pvt. Ltd., p.34. This is particularly true in case of companies limited by guarantee where the shareholders agreed to guarantee the debts of the company to a certain extent beyond their contribution, in case the company becomes unable to meet its debts. This possibility is not also totally closed even under Ethiopian law. This is because there is no clear prohibition from making the liabilities of shareholders unlimited through their mutual agreement (for the benefit of third party creditors). However, in case of General Partnership, it is not possible to make the liabilities of partners limited by their article of association as the provision of the law is mandatory.

${ }^{22}$ Cheng Thomas K. (2010) 'Form and substance of the doctrine of piercing the corporate veil', Mississippi Law Journal, Vol. 80, No. 2, p. 510.

${ }^{23}$ Commercial Code, supra note 17, Arts. 255 (2), 280, 296. 
opportunities, the nation's economic and financial growth, stability and prosperity. $^{24}$

Since the liability of the shareholders (members) is limited to their contribution, the company's creditors cannot extend their hands to the personal property of the shareholders. Hence, due to the protection it offers to shareholders, the attribute of limited liability of a company is known as the veil or shell of a company. This is because this attribute covers the shareholders in the corporate veil and keeps them from the reach of outsiders (creditors). The veil or shell is the corporate personality of the company.

Although limited liability is an advantage for shareholders, it may, however, greatly affect the traditional debtor-creditor relationships. Limited liability can have negative effects on creditors in different ways. First, it opens opportunities for both express and tacit misrepresentation in transactions with creditors. Shareholders who employ the company's name through which to contract with others may misrepresent the assets of the company and simply walk away if the business fails. ${ }^{25}$ Second, limited liability makes it possible and sometimes attractive to shift assets out of the company after a creditor has extended credit to the company. ${ }^{26}$ It would be easy for shareholders to distribute assets to themselves (particularly in case of one-man and family companies) while leaving the debts with their company in violation of creditors' right. Or more subtly, shareholders or directors may undertake highly risky (volatile) investments or increase leverage in order to shift uncompensated risk onto the shoulders of creditors. ${ }^{27}$

All of these opportunistic moves, however, would lose much of their appeal if shareholders did not have the shield of limited liability to protect their personal assets from the consequences of contractual default on the part of the company. This and other factors necessitate the application of the doctrine of lifting (piercing) the veil which involves disregarding the attribute of legal personality of a company and reaching to the shareholders and other persons involved in the management of a company who are protected by the veil.

${ }^{24}$ Jesse H. Choper, Jhon C. coffee and Robert Morris Jr. (1989), Cases and materials on corporations, $\left({ }^{\text {rd }}\right.$ ed.), case book series, (Canada: Little Brown and Company Ltd.), p. 145

25 Allen William T., Kraakman Reinier, and Subramanian (2007), Commentaries and cases on the law of business organizations, $\left(2^{\text {nd }}\right.$ ed.), New York: Aspen publishers, p. 131

${ }^{26}$ Ibid, p. 132.

${ }^{27}$ Ibid. 


\section{The Meaning and Origin of the Doctrine of Piercing the Corporate Veil}

The independent legal status of the corporate entity which constitutes 'the corporate veil' or 'the shell of a company', serves as a curtain between the company and its members and is regarded as a privilege for the shareholders as it protects them from the risk of unlimited liability for the debts of the company. ${ }^{28}$ However, this privilege of limited liability may not always exist for certain reasons including when the legal personality of a company is used for illegitimate or unlawful purposes. If it is shown that the legal personality has been abused and used to the detriment of third parties (creditors), the theory of distinct legal personality (i.e. the separate and distinct existence of the company from that of its members) is disregarded. ${ }^{29}$ Consequently, the individual members will be held liable for the wrongs caused through the use of the legal entity. Hence, when this is done by courts or sometimes by statute, it is said that the corporate entity is disregarded or the veil of a company is pierced.

The doctrine of piercing the corporate veil has its origin in the common law legal system particularly in England. ${ }^{30}$ Originally, it was a reaction to a rigid stand of the House of Lords on a famous decision that is known for establishing the principle of distinct entity of the company. In the Salomon v. Salomon \& Co. Ltd case (as stated above) the House of Lords decided that a corporation is different from its share holders, stating that: "the company is at law a different person altogether from the subscribers to the memorandum; .... and it is not in law the agent of the subscribers or trustee for them. Nor are the subscribers as members liable, in any shape or form." $" 31$

Therefore, this decision established not only one of the most important principles of corporate personality that a company is a distinct entity apart from that of its shareholders, but it also led to the development of its exception, i.e. the doctrine of 'piercing the corporate veil'. ${ }^{32}$ After this case decision, the realization that the corporate personality could be used in a fraudulent manner

${ }^{28}$ Bagrial, supra note 21, p.35.

${ }^{29}$ Ottolenghi, S. (1990) 'From Peeping behind the Corporate Veil, to Ignoring it Completely', the Modern Law Review, Vol. 53, No. 3, Blackwell publishing, p.339.

${ }^{30}$ Bruck Kefyalew (2003), Lifting the Corporate Veil in Corporate Groups Under the Commercial Code of Ethiopia, Senior Thesis, Faculty of Law, Addis Ababa University, (unpublished), p.60.

${ }^{31}$ Griffin Stephen, supra note 4, p. 8.

${ }^{32}$ Such terms as "lifting the veil", "breaching the wall of a company", "dislodging the corporate veil" or "piercing the corporate veil" are all legal terms of arts used to denote the same thing (i.e. the denial of the privilege of legal personality and limited liability). 
came into focus. Consequently, the doctrine of piercing the corporate veil began to assume a certain shape and form and became recognized in different forms both in the common law and civil law legal systems.

\section{The Grounds of Piercing the Corporate Veil in Foreign Laws}

Certain conditions may justify lifting the limited liability protection accorded to the shareholders of a company. However, a consistent guiding principle has not yet evolved to enable us to predict with any certainty as to when the courts will lift the veil of a company. ${ }^{33}$ It is still impossible to discern any broad principle of company law indicating the circumstances in which a court should lift the corporate veil. Rogers AJA describes the authorities for piercing the corporate veil as "incoherent and unprincipled" stating that:

[t]here is no common, unifying principle, which underlies the occasional decision of the courts (mainly common law courts) to pierce the corporate veil. Although an ad hoc explanation may be offered by a court which so decides, there is no principled approach to be derived from the authorities. $^{34}$

The common law courts have repeatedly asserted that the doctrine of piercing is an equitable one and its application requires weighing the totality of the circumstances. Many countries apply a two-prong (tier) test to piercing the corporate veil. First, there must be such a unity of interest and ownership between the company and its owners that their separate personalities should cease to exist in reality. ${ }^{35}$ These factors include lack of substantive separation between the shareholders and the company, shareholder domination, and overlap of corporate personnel and management. ${ }^{36}$ Second, an adherence to separate corporate personality should create inequitable results (injustice). That is, an inequitable result should occur if the acts are treated as those of the company alone (a fairness requirement). ${ }^{37}$

Hence, the determination of a veil piercing requires the judge to ascertain facts such as the extent of overlap in corporate personnel, and the degree of

${ }^{33}$ Susan Barber, (ed.) (2001), Text book of Company Law, ( $3^{\text {rd }}$ ed.), London: Old Bailey Press, p. 12.

${ }^{34}$ Rams Ian M. and Noakes David B. (2001) 'Piercing the corporate veil in Australia', Company and Securities Law Journal, Vol.19, p. 4.

${ }^{35}$ Backer Larry (2002), Comparative Corporate Law: United States, European Union, China and Japan, Cases and Materials, (Durham: Carolina Academic Press), p. 987.

${ }^{36}$ Ibid.

${ }^{37}$ Ibid. 
shareholder domination of the company, unity of interest and ownership, and these should be evaluated in light of the doctrine's underlying values of good faith and fairness. ${ }^{38}$ Principally, whether the corporate entity should be set aside comes down to a question of good faith and honesty in the use of corporate privilege for legitimate ends. ${ }^{39}$ It is asserted that veil piercing is justified when the notion of legal entity is used to defeat public convenience, justify wrong, protect fraud, or defend crime. ${ }^{40}$ These statements suggest that the corporate veil doctrine requires good faith and fair use of the corporate entity. In relationships with creditors, this duty of good faith and fairness (as principles of truth and respect) are some of the substantive objectives of the legal order.

In short, piercing the corporate veil doctrine is non-conclusive. With its reference to desirable values and its non-conclusiveness, the corporate veil doctrine exhibits the open-endedness of a standard. That is, there is no single uniform standard for deciding and justifying veil piercing. The courts make a determination based on notions of fundamental fairness and justice on a caseby-case basis. However, there are, as discussed below, some grounds of piercing that are usually stated in English law and French law.

\subsection{Piercing the corporate veil in case of fraudulent abuse (fraud exception)}

Piercing the corporate veil may be justified when the formation and subsequent existence of a company constitutes a fraudulent abuse of the company. ${ }^{41}$ The fraud exception considers the formation of a company to be a sham or façade. ${ }^{42}$ To justify this exception, a company must have been formed for an improper or illegitimate purpose. Ordinarily, the fraud exception will operate where the underlying motive for formation was to enable the company's human constituent(s) to impugn a pre-existing obligation with a third party (i.e. to evade contractual obligations). In such cases the common law courts in England

${ }^{38}$ Cheng Thomas K., supra note 22, p. 509.

${ }^{39}$ Ibid, p. 508.

${ }^{40}$ Ibid.

${ }^{41}$ Griffin Stephen, supra note 4, p.14.

${ }^{42}$ Rams Ian M., supra note 34, p. 12. A company is said to be a Sham or façade if the company is formed or used as a "mask" to hide the real purpose of the company's controller. A 'sham' is something that is intended to be mistaken for something else or that is not really what it purports to be. It is a spurious imitation, a counterfeit, a disguise or a false front. It is not genuine or true, but something made in imitation of something else or made to appear to be something which it is not. It is something which is false or deceptive. As noted above, a "fraud" exception is dependent upon a "sham" argument as the courts have held that no fraud can be perpetrated where the company is real and not a façade. 
may recognize the existence of the corporate entity but may nevertheless pierce the corporate veil to prevent individuals involved in the illegitimate activity from escaping a liability that otherwise would have been enforceable had the individual(s) concerned not sought to hide behind the company's separate legal status. $^{43}$ Thus, the motive for which a company is formed is the most relevant in determining whether a corporate veil should be pierced to impose liability on the members of the company.

An example of cases in which the veil of a company is pierced on the ground of fraud exception was the Gilford Motor Co. Ltd V. Horne [1933] Ch 935, ${ }^{44}$ (Court of Appeal) in which Mr. Horne entered into a contract with Gilford Motor Co. Ltd by which he agreed to abide by a restrictive covenant which provided that should he leave Gilford's employment (as he was a managing director of Gilford Motors Co.), he would not solicit their customers. Upon leaving Gilford's employment, Horne (through nominees) formed a company (JM Horne \& Co. Ltd, in which his wife and an employee were sole shareholders and directors). He thus impliedly sought to escape the terms of a restrictive covenant. The court held that "the company was a 'sham', an alias of Horne, and as such an injunction was granted to enforce the covenant." The restrictive covenant was enforced against both Horne and the company, that is, the company's corporate existence was not denied although the company's corporate veil was pierced to recognize Horne's personal culpability for the breach of the restrictive covenant. ${ }^{45}$ In effect, Horne had established a company as a fraudulent device to escape the terms of a pre-existing contractual obligation entered into with the Gilford Motors Co. Ltd. These types of companies are regarded as a 'sham' or 'façade' used to mask the real situation and justifies veil piercing.

\subsection{Piercing the corporate veil to establish a single economic entity}

This ground of piercing applies if there is a unity of interest and ownership between the company and its owners that their separate personalities have ceased to exist in reality. ${ }^{46}$ This occurs when there is lack of substantive separation between the shareholders and the company, and overlap of corporate personnel and management. Even though more than two separate companies are

${ }^{43}$ Griffin Stephen, supra note 4, p. 15.

${ }^{44}$ Sealy Len and Worthington Sarah (2008), Cases and Materials in Company Law, $\left(8^{\text {th }}\right.$ ed.), London: Oxford University Press, p.62.

${ }^{45}$ Ibid.

${ }^{46}$ This clearly indicates that the mere use of a subsidiary does not necessarily subject a parent corporation for the liabilities of a subsidiary corporation. 
established, the law will consider them as one and single economic entity if they are not operated as wholly separate entities, but instead combine their resources to achieve a common business purpose. ${ }^{47}$

This ground of piercing the corporate veil grounds itself on two interrelated theories: the "alter ego" 48 theory and "single enterprise theory" 49 of piercing the

${ }^{47}$ The law in Texas regarding piercing the corporate veil, p. 6, available at $<$ http://www.pdfcari.com/The-Law-in-Texas-Regarding-Piercing-the-Corporate-VeilSection-1-....html> Accessed: February 10, 2011).

48 The 'alter ego' theory also called 'another self' theory permits a court to impose liability upon an individual shareholder, officer, director, or affiliate for the acts of a company. This theory may also be used to impose liability upon a parent company for the acts of a subsidiary company when the subsidiary is "organized or operated as a mere tool or business conduit." A court will look at many factors to determine whether an alter ego relationship exists. When dealing with an individual and a company, the court will look at the total dealings of the company and the individual, including evidence of the degree to which company's assets and individual property have been kept separate; the amount of financial interest, ownership, and control the individual has maintained over the company; whether the company has been used for personal purposes. In these cases the court will disregard their separate personality and consider them as a single entity working in a different form or shape. (See the law in Texas regarding piercing the corporate veil. Pages 1-5 cited above).

${ }^{49}$ The "single enterprise" theory of piercing the corporate veil is another interconnected theory to the theory of "alter ego" which is used to impose liability when businesses integrate their resources. In order to take advantage of the company's form of limited liability, parties will often form several different business concerns under the belief that each formed entity will protect them from any and all personal liability of each business concern. Courts, however, apply the single business enterprise theory to pierce the corporate veil in situations where two or more companies are not operated as wholly separate entities, but instead combine their resources to achieve a common business purpose. When courts find that a single business enterprise exists, they will hold each company liable for the obligations of the other relating to the common business purpose to avoid an 'inequitable outcome.' The courts used a 'single enterprise' theory to pierce the corporate veil in order to reach the assets of a subsidiary's parent company or to reach the assets of any other entity involved in the single business enterprise. Courts have listed several factors that are to be considered when determining whether a single business enterprise exists. These factors, though not cumulative and exhaustive, include having common employees, common shareholders, common officers, centralized accounting, payment of wages by one company to another company's employees, services rendered by the employees of one company on behalf of another company, unclear allocations of profits and losses between companies, undocumented transfers of funds between companies etc. (see the law in Texas regarding piercing the corporate veil, pp. 6-8). Both the 'alter ego' and 'single enterprise' theories are inter-related as the purpose and effect of the two 
corporate veil. There are different situations by which the corporate veil is pierced based on this ground of a single economic entity. The first situation relates to the case of group of companies (parent-subsidiary or sister companies). In this case, courts may pierce the veil of a company to allow a group of companies to be regarded as one, if they are not, in reality, independent either in human or commercial terms ${ }^{50}$ Piercing the corporate veil to establish a single economic entity removes the corporate veil of the subsidiary (subservient) company, merging that entity with the dominant entity (holding company), or merging sister companies thereby constituting a single economic entity. An economic entity may be deemed responsible for the activities of both the dominant and the subservient parties ${ }^{51}$ or to the debts of sister companies.

The illustrative (non-exhaustive) factors the courts should consider in this regard include common stock ownership between parent and subsidiary, common directors and officers between parent and subsidiary, parent's financing of the subsidiary, parent's payment of salaries and other expenses of subsidiary, parent's use of subsidiary's property as its own, and the extent to which directors and officers of subsidiary are acting independently or in the best interests of the parent. ${ }^{52}$ The presence of these factors verifies that the unity of interest is more complete and the exercise of control over the subsidiary is more intimate, thereby justifying veil piercing.

The other situation by which the corporate veil is pierced on the ground of establishing an economic entity is the case of one-man company. One-man companies face a great threat of having their legal personality disregarded. This is because there is abundant chance for the mingling (mixing) of personal and company assets and for the complete control (domination) of company's policy. ${ }^{53}$ A mere proof that one man owns all the shares of a company cannot destroy its separate entity unless the following circumstances occur. First, the company must be influenced and governed by the sole owner and a unity of interest and ownership ought to exist in such a manner that the individuality or separateness of the said person and company has ceased. ${ }^{54}$ Second, the facts should show that an adherence to the fiction of the separate existence of the

theories is identical: to allow a plaintiff to recover from another party when a company does not have adequate assets.

50 Keenan Denies (2009), Smith \& Keenan's Company law, (12 $2^{\text {th }}$ ed.), Pearson Longman, Book aid international, p. 26

${ }^{51}$ Griffin Stephen, supra note 4, p. 16.

${ }^{52}$ The law in Texas regarding piercing the corporate veil, supra note 47, p. 3.

${ }^{53}$ Wormser I. Maurice (1912), 'Piercing the veil of corporate entity', Columbia Law Review, Vol. 12, No. 6, Columbia law review association Inc., p. 504.

${ }^{54}$ E. O. E. (1925) 'Corporations: Disregarding Corporate Entity: One Man Company', California Law Review, Vol. 13, No. 3, California law review Inc., p.238. 
company would, under the particular circumstances, sanction a fraud or promote injustice. ${ }^{55}$ That is, the facts set forth should disclose that the dealings were in form with a company but in reality with an individual, and that a refusal to recognize this fact will bring about inequitable results. Third, the company must be the corporate double (alter ego) of the sole shareholder. ${ }^{56}$ In other words, the shareholder must have confused (mixed) the company's business with his other affairs and an application of the conception of separate personality of the company must lead to injustice.

In other words, where a company is the instrumentality through which an individual (who is the sole shareholder transacts his business), the company will be bound by the acts of the sole shareholder just as he would be bound if the company did not exist. Where the sole shareholder does not distinguish between the company's business and his individual affairs, there is no reason for the court to make this distinction. ${ }^{57}$

Generally, to pierce the corporate veil either in parent-subsidiary companies or in a one-man company on the ground of establishing a single economic entity, the courts must consider the extent to which the financial affairs and accounts of a company and those who control it are confused (mingled) to the prejudice of creditors, the undue diversion of its funds to individual use, and the holding out of a subsidiary as a mere department, branch or part of the system. ${ }^{58}$ However, the above factors are stated in general terms and the courts are given discretion to appraise a particular situation in each case.

\subsection{Piercing the corporate veil on the ground of agency}

Where the company is acting as an agent of the shareholders, then the latter will be held liable for its acts. There may be an express agreement ${ }^{59}$ to this effect or such agreement may be implied from the facts of a particular case though there is no express agency agreement. ${ }^{60}$ In other words, the concept of agency has sometimes been used by the courts under which the subsidiary is regarded as an agent $^{61}$ of its holding company (sole owner in case of one-man company), even

${ }^{55}$ Ibid, p.239.

${ }^{56}$ Ibid.

${ }^{57}$ Ibid, p. 237.

${ }^{58}$ Seifu Tekle Mariam, supra note 3, p.13.

${ }^{59}$ Gulshan S.S and Kapoor G.K. (1991), Company law: Including MRTP Act, FERA and Interpretation of Statutes, (New Delhi: Wiley Eastern Limited), p. 5.

${ }^{60}$ Keenan Denies, supra note 50, p. 27.

${ }^{61}$ In the context of an agency relationship between corporate entities, agency may be tentatively defined as a relationship which is based upon the express or implied consent of both the subsidiary company and its holding company (sole owner in case 
though there is no agency agreement as such between them in regard to the transaction concerned. The effect is that the transactions entered into by a subsidiary are regarded as those of the holding company (sole owner in case of one-man company) for which the latter is liable.

Although an agency relationship may establish the existence of an economic entity, it must be noted that in terms of pure theory, an agency relationship creates no disturbance to the subsidiary's corporate veil because to establish an agency relationship one must have a principal and an agent, that is two distinct legal entities. ${ }^{62}$ Therefore, as a legal concept, agency is not a device which pierces a corporate veil, albeit, notwithstanding the theory, the finding of agency relationship between two distinct entities will result in the same effect as if the corporate veil had been lifted, namely the principal (the holding company or a sole owner in case of one-man company) will be liable for the actions of its agent (the subsidiary company or one man-company). ${ }^{63}$ It seems, therefore, that agency relationships are established by the courts with the sole aim of finding the principal responsible for the acts of his 'agent'. The basis for their judgment is that the principal has made his agent act according to specific instructions, thus depriving 'the agent' of any willpower of its own. ${ }^{64}$ This technique of imposing an agency relationship is used by the common law courts when they are reluctant to lift (or pierce) the veil completely (referred to as real lifting of the veil), but achieve the same result as that of piercing the veil.

This ground of piercing the corporate veil is mainly implemented for purposes of liability to tax. ${ }^{65}$ If the purpose for which a company is established is for tax-evasion or circumvention of tax obligation, the court may not recognize the separate legal existence of the company.

The foregoing discussion shows that the common law courts have used elastic and flexible terms such as "equity, fraud, single economic entity, agency or instrumentality" as grounds to pierce the corporate veil and to reach to those persons who have used the corporate device for various improper purposes and

of one-man company), whereby the subsidiary company is made subject to the holding company's control and will and to the extent that the subsidiary conducts its business affairs for the ultimate benefit of the holding company (sole owner). Therefore, to establish agency in group relationship, it is crucial to prove that one dominant company (sole owner) exerts absolute control over the affairs or acts of the other company.( see also Griffen Stephen, company law: fundamental principles, p.21, cited above).

${ }^{62}$ Griffin Stephen, supra note 4, p.21.

${ }^{63} \mathrm{Ibid}$.

${ }^{64}$ Ottolenghi S., supra note 29, p. 346.

${ }^{65}$ Gulshan, supra note 59, p. 4. 
to grant justice (remedy) for those wronged. Although the doctrine of piercing the corporate veil has its origin in the common law legal system, it has influenced the civil law legal system at large. The French legal system ${ }^{66}$ provides some statutory provisions and judicial grounds by which the corporate veil may be pierced. One of the statutory grounds of piercing the veil in French law is in case of bankruptcy. Under French law, shareholders or persons who have acted as managers and any person who has used the company's property as his/her own and benefited therof shall be liable for the debts of the company when its assets become insufficient to pay off creditors. ${ }^{67}$

The reason for making the managers liable for the debts of a company is the presumption of the law that they have failed to be diligent and careful in managing the affairs of the company. However, the liability may not be imposed where the manager and the other administrators concerned prove that they have performed the obligations incumbent upon them in respect of the affairs of the company completely and with due diligence. ${ }^{68}$ However, absence of actual participation in management or supervision of the company, after assuming such a position, cannot be a defense to escape from liability. ${ }^{69}$ Hence, bankruptcy is the most important and frequent situation in which the French law pierces the corporate veil.

The other situation of statutory piercing of the corporate veil in French laws is with respect to the controlling shareholder who owns more than half of the shares of a company, or controlling shareholders whose shares enable them to have the majority vote. French law attempts to pierce the corporate veil and make the controlling shareholder(s) liable for the debts of the company. The controlling shareholder could be a holding company or an individual shareholder. However, the mere fact that a person is the controlling shareholder of a company does not render him/her liable for the debts of the company. Where the controlling shareholder has acted properly within the limits of his/her legal rights, no such liability is incurred. This is particularly true where the

${ }^{66}$ The author surveyed some grounds of piercing the corporate veil in the French Law, despite its origin is in the common law, because our country, at least in principle, belongs to the civil law legal system and the French law has been the direct source of our Commercial Code of 1960.

${ }^{67}$ Lutter Marcus (1973), 'Limited Liability Companies and Private Companies', Vagts D., (ed.), International Encyclopedia of Comparative Law, Vol. XIII, Martinus Nijhoff Publishers, p.102

${ }^{68}$ Chon E., supra note 20, p. 206.

${ }^{69}$ Ibid, p. 208. 
minority shareholders were able to exercise their own rights of opposition and supervision. $^{70}$

Piercing may apply where a parent or holding company fails to apply (in its dealings) the necessary distinction between its own assets and those of its subsidiary. ${ }^{71}$ It was consequently applied in a case in which a subsidiary had been established with capital from the holding company whose board habitually issued instructions to the board of the subsidiary on the management of the latter's affairs. The dependence of the subsidiary on the parent company was furthermore underlined by the fact that the parent company used the subsidiary for the purpose of fraudulent transactions, including the concealment of assets owned by the parent company. ${ }^{72}$

This statutory piercing is similar to the common law piercing on the ground of establishing a single economic entity. This fact is affirmed by the statutory provision of the French Commercial Code which states that "any capital held, even where this is less than $10 \%$, by a controlled (subsidiary) company shall be regarded as being indirectly held by the company controlling the latter.",73

Similarly, the controlling individual shareholder will be liable if he did not manage the company as if it was a separate entity, but treated it as a personal enterprise of his/her own.

...[I]t has been held that a person who either directly or through a nominee owned the majority of the shares of a company was personally responsible for the debts of the company if he acted arbitrarily as maitre de l'affaire and treated the company's assets as if they were his own. Such a state was assumed to exist in a case in which, in fact, the participation of the other shareholders was found to be of no practical or economic importance, or where actual accounts were in fact not issued or where the board of management or the assembly of shareholders existed merely on paper and were in fact not convened or in cases in which the company effected sales without issuing and dispatching to its customers proper invoices, thus enabling the controlling shareholder to appropriate the cash resulting from the payment of the purchase price by the customer. ${ }^{74}$

These are some of the situations by which the French legislator has provided statutory solutions to the issue of disregarding the corporate entity. There are also some non-statutory grounds of judicial piercing in France. Although the

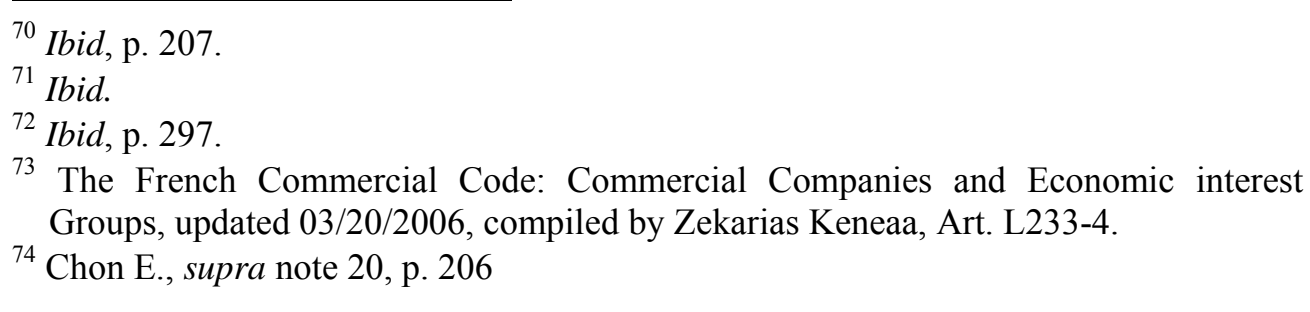


statutory provisions were mainly applied, French courts have in fairly few instances found it necessary to lift the corporate veil. One of the cases in which the corporate veil was lifted by French Courts relates to cases in which valid agreements in restraint of trade was concluded. An obligation validly entered, by which one party bound itself not to establish a competitive business in a defined area, cannot be evaded by the formation of a company which is intended to run a business in the interest of the promisor. ${ }^{75}$ This is similar to the common law case of Gilford Motors Co. Ltd v. Horne, stated above, in which Horne, through nominees, formed a company (JM Horne \& Co. Ltd) through which he impliedly sought to escape the terms of a restrictive covenant.

The other case by which the French courts pierce the corporate veil is in case of defacto companies (companies existing in fact without fulfilling the requirements of the law). This is particularly when a company fails to maintain the minimum membership requirements of a company. If the company members are reduced below the legal minimum, the remaining members of a company who are aware of the reduction of membership below the legal minimum will be jointly and severally liable for the debts of a company incurred six months after such reduction happens. This ground of piercing is applied by the courts for public limited companies and not for limited liability companies ${ }^{76}$, as limited liability companies can be operated even by one person. ${ }^{77}$ However, in case of public limited companies the number of members may not be less than seven. ${ }^{78}$ Hence, if the number of members is below seven, the remaining members cognizant of the fact of such reduction will be jointly and severally liable for all the debts of a company incurred six months from the date of such reduction. Moreover, they cannot invoke the nullity of the company against third parties, but third parties may use the nullity against the shareholders, managers or directors. In case of bankruptcy, they may be directly declared bankrupt without

${ }^{75}$ Ibid, p. 210

${ }^{76}$ The French law recognizes two types of companies with separate legal existence and limited liability of the members. These are Limited Liability Company (LLC), which can be formed by one or more persons who shall be liable only in respect of their contributions and designated by the name, in which may be contained the names of one or more members and which must be immediately preceded or followed by the words "Societe A Responsabilite Limitee" or the initials "SARL; and Public Limited Company, a company whose capital is divided into shares and which is formed among members who shall bear any losses only up to the amount of their contributions. It is also called Societe Anonyme (SA).

${ }^{77}$ The French Commercial Code, supra note 73, Art. L 223-1

${ }^{78}$ Ibid, Art. L 225-1 
first going into the bankruptcy of the company as there is no company at law to be declared bankrupt and proceeded against. ${ }^{79}$

\section{The Statutory and Judicial Recognition of Piercing the Corporate veil in Ethiopia}

The Ethiopian Commercial Code recognizes two types of companies: Private Limited Company ${ }^{80}$ and Share Company. Share Companies can be formed in two ways. ${ }^{81}$ Both types of companies, after fulfilling the legal requirements, will acquire legal personality and the attribute of limited liability of shareholders (members). The Commercial Code vests legal personality, which is the most important attribute, on all types of business organizations except a joint venture. ${ }^{82}$ Due to its separate legal personality, a company is a subject of rights and obligations, in its own right, distinct and separate from its shareholders, directors and managers. It may therefore, enter into contracts not only with the

${ }^{79}$ Seifu Tekle Mariam, supra note 3, p.19

${ }^{80}$ Commercial Code, supra note 17, Art. 510. A private limited company is a company consisting of two to fifty members who are liable only to the extent of their contribution. It is always commercial in form and governed by the Commercial Code provisions of Arts. 510- 543 and the general provisions applicable to all forms of business organizations (Arts. 210-226).

${ }^{81}$ One way of forming a share company is formation as between founders without offering the shares for public subscription (Art. 316 of the Commercial Code of Ethiopia). These types of Companies are sometimes called closely held or Family Share Companies. In this case, the memorandum of association shall indicate the fact that all the shares have been allocated, one quarter of the value of the shares have been deposited in a bank and the valuation of contribution made in kind, if any, has been made in accordance with the law and that the administrative organs of a company are established. The other way of formation of Share Companies is by offering shares for public subscription through a prospectus signed by all the founders (Arts. 317, 318 of the Commercial Code). The prospectus shall be made in such a way that it would help the offerors (subscribers) know the price of shares, time of payment, summary of the memorandum and articles of association. Artsicles 318322 will apply for such share companies which is not the case in closely held share companies. However, except for some provisions related to its formation, both types of share companies are subject to the same provisions of the Commercial Code (Arts. 304- 509 and the general provisions applicable for all business organizations (Arts. 210-226)).

${ }^{82}$ Commercial Code, supra note 17, Art. 210 (2). The term 'joint venture' as used in the Commercial Code refers to Societe Annonymes, (yeashmur mahiber in the Amharic version). It binds the parties in but lacks juridical personality in relationships with others. Recent proclamations however use the word 'joint venture' under a different context. 
world outside itself but also with its members, sue and be sued, has the right to possess property and capital by selling its shares, the power to compromise bona fide disputes etc. ${ }^{83}$ However, since a human agent is necessary to exercise those rights and respond to the duties, a company acquires rights, incurs liabilities and acts in legal proceedings only through its agents. ${ }^{84}$

The other attribute of Ethiopian companies is limited liability of the shareholders (members). Art. 510(1) of the Commercial Code provides that "a private limited company is a Company whose members are liable only to the extent of their contributions." Although the Commercial Code provides for the liability of members instead of first providing for corporate liability, it is obvious that the corporate liability of a private limited company is limited to its assets. Similarly, according to Article 304 of the Commercial Code the liabilities of a share company are limited to the total value of its assets. ${ }^{85}$

Assets are the sum total of what a company owns. ${ }^{86}$ The total initial contribution from members (i.e. the sum total of the par value of all shares issued) constitutes the capital of a company, as enshrined under Articles 306 and 512 of the Commercial Code. The amount contributed by shareholders in excess of the par value (face or nominal value) of the share is known as issue premium $^{87}$ and is not part of the capital but is still part of the assets of a company. ${ }^{88}$ The other components of the assets of a company, particularly a share company, are the various types of reserves created from the profits generated by the company itself. Reserves may take different forms, namely, legal reserve, supplementary reserve, optional reserve and free reserve depending on the source that created them. ${ }^{89}$ All these constitute assets of the company against which creditors may proceed for the satisfaction of their claims and no shareholder is personally liable so long as s/he has made her/his

${ }^{83}$ Seyoum Yohanness (2008) 'On the Formation of Share Companies in Ethiopia', Journal of Ethiopian Laws, Vol. 22, No.1, p.104

${ }^{84}$ Commercial Code, supra note 17, Art. 216.

${ }^{85}$ Ibid, Art. 304(1).

${ }^{86}$ Seyoum Yohanness, supra note 83, p.106.

${ }^{87}$ Commercial Code, supra note 17, Art. 326. Shares can be classified as share at discount and shares at premium based on the price at which shares are issued. Shares at discount are shares issued at a price lower than its par (face) value. However, under Ethiopian law share at discount are totally prohibited. On the other hand, premium shares are shares issued at a price greater than the par value where such issue is provided by the memorandum or article of association or decided by an extraordinary general meeting. The difference between the par value and the price at which the shares are issued shall be known as a premium.

${ }^{88}$ Seyoum Yohanness, supra note 83, p.106.

${ }^{89}$ Commercial Code, supra note 17, Art. 453(2(d)). 
promised contribution. That is, once the shareholder has paid the par value and any premium agreed, s/he is no longer liable to contribute anything further towards meeting the company's debts and liabilities.

The logical questions that follow are, therefore, is the legal personality of companies always respected under Ethiopian laws? Can shareholder(s), director(s) or manager(s) of a company do whatever they wish under the cover of limited liability and separate legal personality of the company? Is there no ground (room) for courts of law to look behind the wall of a company and make the human constituents liable? The next sections of the article address these issues.

\subsection{Grounds for piercing the corporate veil in Ethiopia}

The Ethiopian Commercial Code provides certain remedies to the creditors of a company against persons who are really responsible for the prejudice caused. Some of these remedies are clearly provided and while others are potential statutory grounds of piercing the corporate veil.

\subsubsection{Piercing the corporate veil in case of bankruptcy}

One of the most serious attempts to safeguard the interest of corporate creditors is provided by the statutory obligations placed upon certain persons in respect of their potential personal liability for the debts and liabilities of the company, following the company's slide into a state of bankruptcy. Articles 531 and 1160(1) of the Ethiopian Commercial Code are the two most important legal provisions in this regard.

With respect to Private Limited Companies, Article 531 of the Commercial Code renders persons who participated in the management of the company that has become bankrupt liable for the debts of the company unless they rebut the presumption of non-diligence by proving that "they have acted with due care and diligence." Article 531(1) provides that "if a private limited company becomes bankrupt and as a result the assets are shown to be inadequate, the court may order the managers or members or both to pay the whole or part of the company's debts separately or jointly." The terms 'managers' and 'members' under this provision respectively refer to non-member managers and member managers; or members who have acted as managers (though not managers per se). This can be understood from the words of sub-art. (2) of the same provision which stipulates that "the liability shall not apply to members who have not acted as mangers" (non-manager members). Therefore, the application of Article 531 of the Commercial Code is restricted only to persons (be they members or non-members) who are managers or who acted as managers of a company. Thus, it is not possible to make all members of the private limited company per se liable during the event of its bankruptcy. 
In short, as per Article 531 of the Commercial Code, piercing applies and manager(s) will be held liable when the company is declared bankrupt and the assets are inadequate to meet its debts. The logical question that may follow is, as to whether piercing can apply when the assets of a private limited company are shown to be inadequate though it is not declared bankrupt? That is, whether judicial bankruptcy is the requirement? One may logically argue that piercing can also apply in this case though the private limited company is not declared bankrupt. In other words, the term "bankruptcy" in Article 531 may not necessarily imply the declaration of bankruptcy but also insolvency (factual bankruptcy) as the legislator seems to have had in mind the falling short of assets of the company to meet its own debts instead of judicial bankruptcy.

Generally, if the company becomes unable to meet its debt, the law takes a presumption that the manager(s) were not diligent or careful in their management. However, the presumption is rebuttable and hence such persons can escape from liability by proving that they have acted with due care and diligence. ${ }^{90}$

Similarly, Article 1160(1) of the Commercial Code, which applies to both share and private limited companies, makes certain persons liable for the debts of the company if it becomes bankrupt. Art. 1160(1) states that "Where a share company or private limited company is declared bankrupt, the adjudication may declare bankrupt any person who has carried out commercial operations on his own behalf and disposed of company funds as though they were his own and concealed his activities under the cover of such company." 91

Therefore, if a share company or private limited company is declared bankrupt ${ }^{92}$ creditors can require the bankruptcy of 'any person' who has carried out the operations in the manner stated in the provision. Although Ethiopian law extends such liability to 'any person' subject to the fulfillment of the conditions stipulated by the law, it does not expressly indicate as to who these persons are.

Under such situations, the Uniform Acts of the Organization for the Harmonization of Business Law in Africa (OHADA) provide for personal bankruptcy of natural persons who are managers or representatives of body corporate whether they are de jure, de facto, remunerated or not, apparent or hidden. ${ }^{93}$ Ethiopian law has no clear provision indicating who these persons are,

\footnotetext{
${ }^{90}$ Ibid, Art. 531(2).

${ }^{91}$ Ibid, Art. 1160(1).

${ }^{92}$ Ibid, Art. 968. A company is said to be bankrupt, it must have suspended payments and declared bankrupt by the court of law as factual bankruptcy cannot be taken as a ground.

93 The Organization for the Harmonization of Business Law in Africa (OHADA),
} 
and seems to extend the bankruptcy to 'any person' (irrespective of whether they are managers, directors or not). Although as a matter of rule, bankruptcy applies only to traders and commercial business organizations ${ }^{94}$ under Ethiopian law, Art. 1160(1) seems an exception to this general rule. Hence, the phrase "any person" in Article 1160(1) of the Commercial Code refers to "any person" (both natural and juristic), irrespective of whether they are managers, directors or not, regardless of whether they are traders or not so long as the conditions stipulated by law are fulfilled.

Therefore, creditors can require the bankruptcy of any of such persons if a share or private limited company is declared bankrupt upon proof of the following three cumulative elements. First, only a person who has carried out commercial activities on his own behalf falls under Article 1160(1). 'On his own behalf' means that the person carried out the business in his personal interest or benefit, or the person has some pecuniary or non-pecuniary interests directly or indirectly accruing to him. ${ }^{95}$ Though a director or a manager, while carrying out commercial operation, has a duty to act in the interest of the company in which $\mathrm{s} / \mathrm{he}$ is a director or manager, it may not always be the case as the director or manager may run the affairs of the company to fulfill his/her own interest. Second, the person must have disposed of company funds as though they were his own. This means that a person treated the assets of the company as his own assets, or used the corporate assets or credit to his own interest at the expense of the company. Although it is not clear as to what the phrase 'company's funds' under Art. 1160 (1) refers to, it is logical to understand that it should not be limited to imply the company's liquid money but rather it includes all properties constituting the company's assets. Third, the person must have concealed his activities under the cover of such company. That is, a person must use the company as a mask to achieve his own purposes at the expense of the latter. Where these three cumulative elements are met, Article 1160(1) of the Commercial Code extends the company's bankruptcy to any person, regardless of whether he/she has served as a manager or director of a company.

It is to be noted that creditors of a bankrupt private limited company have a dual option to exercise their claim. First, they can base their claim on Art. 531 of the Commercial Code and proceed against managers or persons that participated in the management of the company without the need to extend bankruptcy proceeding of the company to the manager. This is because the creditors shall not have the burden of proving that the manager(s) were not diligent or careful in their administration of the company since the law makes a presumption of

Uniform Act Organizing Collective Proceedings for Wiping off Debts, Art. 194.

${ }^{94}$ Commercial Code, supra note 17, Art. 968 cum. 1155.

${ }^{95}$ Seifu Tekle Mariam, supra note 3, p.24. 
non-diligence. Moreover, the three conditions of Art. 1160 discussed above need not be proved by the creditor in bankruptcy. For creditors of private limited company this is a preferable action, if the manager could be able to meet the claim. Secondly, if it is not possible to recover the debts from managers according to Article 531, they may require the court to extend the bankruptcy to such persons as per Article 1160(1) of the Commercial Code upon the burden of proving the conditions required by law.

\subsubsection{Piercing the corporate veil in case of failure of directors to discharge duties diligently}

Director(s) are responsible for exercising the duties imposed on them by law, the memorandum and articles of association or resolution of the meetings of shareholders, with the care due from an agent. ${ }^{96}$ Accordingly, director(s) will be held liable to the company's creditors where they fail to preserve intact the company's assets and consequently the assets become insufficient to meet liabilities.

According to Article 366 of the Commercial Code, the liability of director(s) is a fault-based liability. In effect, they are liable only upon failure to preserve the assets of the company intact thereby causing the insufficiency of its assets to meet its debts. Where the company's assets are insufficient to satisfy the claims of the creditors, the latter may proceed against the director(s) for the payment of their unsatisfied claims. When the company's assets are shown to be insufficient, the directors are presumed to have failed to keep the company's assets intact. The only way out for the directors is to show that they have acted with due care and diligence. They would not be liable to third parties if they could show to the satisfaction of the court that they have carried out their duty diligently and carefully. ${ }^{97}$ The presumption of the law for failure of directors to carry out their duty, in case where the assets of the company becomes insufficient to satisfy the claims of creditors, shifts the burden of proof to the directors themselves. Moreover, the resolution of the general meeting not to institute proceedings against the directors would not relieve the delinquent director(s) from personal liability as a consequence of a wrongful act. ${ }^{98}$

Contrary to the argument of Seifu Tekle Mariam who restricts the application of Article 366 of the Commercial Code to cases when the company is declared bankrupt, the author of this article argues that the proper application of Article 366 applies even before the judicial declaration of bankruptcy. If Article 366 only applies to companies that are judicially declared bankrupt, it would be

${ }^{96}$ Commercial Code, supra note 17, Art. 364(1).

${ }^{97}$ Ibid, Art. 364 (5).

${ }^{98}$ Ibid,, Art. 366 (3). 
redundant and serves no purpose as the liabilities of directors in case of bankruptcy are already addressed by Article 1160 (1) of the Commercial Code, as discussed above.

For a company to be bankrupt, two cumulative conditions should be satisfied. These are suspension of payment ${ }^{99}$ and declaration of bankruptcy. ${ }^{100}$ Factual bankruptcy does not make a company bankrupt. In other words, where no judgment in bankruptcy is given, bankruptcy shall not result from mere suspension of payments. ${ }^{101}$

The requirements for the personal liability of director(s), according to Article 366 of the Commercial Code, are their failure to preserve the company's assets intact and the resultant insufficiency of the company's assets to meet its liabilities. Only one of the conditions for bankruptcy (i.e. suspension of payment and not judgment of bankruptcy) is thus required to make director(s) liable for the debts of a company under this legal provision. Therefore, this clearly amplifies the fact that Article 366 of the Commercial Code shall apply to make director(s) liable for the debts of a company without requiring the company to be declared bankrupt. It is also to be noted that this provision shall à fortiori apply in case of bankruptcy as well. Therefore, this is one of the statutory stipulations that render director(s) and manager(s) liable for the debts (liabilities) of the company on the ground of "failure to discharge duties diligently" under Ethiopian law.

\subsubsection{Piercing the corporate veil upon reduction of members below the legal minimum}

A share company shall not have less than five members and it is always commercial in form irrespective of its objects. ${ }^{102}$ Failure to maintain this minimum required number of members may lead to the dissolution of the company and liability of members for the debts of a company. In this regard, Article 311 of the Commercial Code states that "no company shall remain in business for more than six months after the number of members is reduced to less than five." The creditors or even the members may make an application, to the court, to order the winding-up of a company if the members are less than five or the company does not possess the prescribed organs. Creditors may make the remaining members, who are aware of such reduction, liable for their claims

99 Ibid, Art. 971. Suspension of payment may result from any fact, act or document showing that the debtor is no longer able to meet the commitments related to his commercial activities.

${ }^{100}$ Ibid, , Art. 969.

${ }^{101}$ Ibid, Art. 970 (1).

${ }^{102}$ Ibid, Art. 10(2). 
as Article 311 of the commercial code states that: “... every member aware of such reduction [of members] shall be personally liable for the debts contracted thereafter."

Therefore, creditors can make the remaining members, who are cognizant of such reduction, liable for the debts of a company incurred after six months from the reduction of members. The liability of the remaining members is not related to the debts incurred before the happening of the reduction of the members, but for the debts incurred within six months from the reduction of the members. The six month period is regarded as a period of "grace" during which the remaining members of a company may avoid personal liability by either reorganizing the company or by filing a petition for the winding-up of a company. This provision is based on the assumption that the danger of abuse of the principle of separate legal personality tends to be greater where the company is controlled by a few or, even worse, by a single person. ${ }^{103}$ This is therefore, a clear ground of piercing the corporate veil under Ethiopian law.

Similarly, a private limited company shall not have less than two and more than fifty members and is always commercial in form. ${ }^{104}$ If the number of members goes below two, the court may order the dissolution of the company upon the application of the creditors or a member after giving reasonable time for the company to make arrangements to comply with the law. ${ }^{105}$ The only remedy available to creditors is requiring the dissolution of a company. Unlike share companies where creditors can make the remaining members personally liable, there is no similar provision regarding private limited companies. Since the purpose of both provisions seems similar - i.e. protection of creditors' interest - there is no valid reason for the legislator not to give similar protection for creditors of private limited companies. Therefore, the law has to be modified to include such provisions or the courts should render justice by extending the provision provided for share companies through purposive interpretation rather than rigid literal reading.

\subsubsection{Piercing the corporate veil in group companies}

The term group companies (also known as related companies) refers to companies related through the ownership of shares, organization of management or through indirect mechanisms that entail control or influence of one company

\footnotetext{
${ }^{103}$ Seyoum Yohanness, supra note 83, p.103.

${ }^{104}$ Commercial Code, supra note 17, Art. 510(2).

${ }^{105}$ Ibid, Art. 511.
} 
by the other. ${ }^{106}$ These related companies may be classified as vertically related (parent-subsidiary) ${ }^{107}$ companies and horizontally related (sister) ${ }^{108}$ companies.

If related companies are formed for abusive purposes, a parent company may, for instance, use its controlling power in the subsidiary company and resort to misconduct and endanger various interests. For example, minority shareholders may have little control as a result of which they are unable to prove the fraud committed by the parent company due to high cost of litigation and unequal bargaining power with the parent company. ${ }^{109}$ Similarly, the creditors of the subsidiary may be highly affected due to the reduction in the solvency of the subsidiary company which could be caused by the parent company's misconduct. ${ }^{110}$ Such misconduct by the parent company which affects creditors is committed under the guise of the principle of separate personality and limited liability. Although the parent company is a member of the subsidiary, both are distinct entities at law and the liabilities of the parent company are limited to its own capital investment. This may be misused as a shield against the creditors of the subsidiaries who are prohibited from pursuing their claims from the parent company whenever the subsidiary fails to meet its liabilities.

Under such circumstances, the laws of different countries protect the interests of the subsidiary company's creditors and lift the corporate veil, either by virtue of statutory provisions or through judicial decisions on the ground of the single economic entity theory or on the basis of agency. This entitles the subsidiary's creditors to proceed against the parent company.

In Ethiopia, the Commercial Code enables a subsidiary company to proceed against a parent company that acts as its director, pursuant to the right given to bodies corporate to act as directors of a company. ${ }^{111}$ Likewise, creditors of a

\footnotetext{
${ }^{106}$ Bruck Kefyalew, supra note 30, p.31.

${ }^{107}$ Ibid, p.35. Vertically related companies are companies related because one company holds majority shares (when a company owning more than $50 \%$ of the voting shares) in the other company or exerts substantial control on the management of the company.

108 Ibid, p.36. Horizontally related companies, also called 'affiliated companies', 'sibling companies' or 'sister companies' exist when there are two or more companies, which have common share holders who are natural persons and who own the whole of these companies as between themselves. These types of companies are created by owners who wish to attain a certain business goal by using multiple companies which function as a single enterprise.

${ }^{109}$ Ibid, p. 52.

${ }^{110}$ Belayneh Ketsela (2006), The need for the regulation of Groups of companies (parent-Subsidiary companies) in Ethiopia, Senior thesis, faculty of Law, Addis Ababa University, (unpublished), p.32.

${ }^{111}$ Commercial Code, supra note 17, Art. 347 (4), 364 (1), cum. 366.
} 
subsidiary can proceed against the parent company acting as a director of their debtor (i.e. the subsidiary) if it fails to perform its duties imposed by law, the memorandum or resolution of meetings and where this causes the insufficiency of the assets of the subsidiary. ${ }^{112}$ This also applies during bankruptcy of the subsidiary by virtue of Article 1160 of the Commercial Code. In such situations, the separate legal personality and limited liability of the parent company may be disregarded and it may be held liable beyond the contribution it has made in the subsidiary company. In this regard, it must be noted that it is only the veil of the subsidiary company which is pierced; and only the parent company, as the shareholder of the subsidiary company, is held liable. Hence, this ground of piercing is known as partial piercing as the shareholders of the parent company are still shielded by the veil of the parent company.

These remedies are available against a director parent company (i.e. when a parent company is chosen as a director of the subsidiary company as per Article 347(4) of the Commercial Code). Therefore, there are no other extensive (sufficient) statutory grounds of piercing in case of parent-subsidiary companies so as to make the parent company liable for the debts of the subsidiary unless the parent company is appointed as a director of the subsidiary under Ethiopian law. The law should indeed consider other grounds of piercing the corporate veil in corporate groups (parent-subsidiary companies) to avoid the abusive behaviors of the parent company and to effectively protect the minority shareholders and creditors of the subsidiary company.

The other avenue of abuse of limited liability may arise when shareholders split a company into various distinct business entities and form sister companies with the hope of minimizing the assets that will be available to the creditors of a company. ${ }^{113}$ Shareholders may also enter into new related business by incorporating a new business entity. ${ }^{114}$

Despite the possibility of such abusive conducts, Ethiopian law does not provide clear provisions as a ground for piercing the corporate veil of sister companies to make one liable for the debts of the other sister company. Hence, the legislator should promulgate adequate laws which provide sufficient statutory grounds to pierce the corporate veil of the sister companies. Under a common law system, judges could have easily played a proactive role in the interest of justice to pierce the veil by considering them as a single economic entity provided that abusive activities exist between the sister companies.

\footnotetext{
${ }^{112}$ Ibid, Art. 366(1).

${ }^{113}$ Bruck Kefyalew, supra note 30, p. 52

${ }^{114}$ Ibid.
} 


\subsubsection{Piercing the corporate veil in case of trade restraint}

The other ground which may call for the application of the doctrine of piercing the corporate veil in Ethiopia is when a person uses the corporate entity to evade his obligations, be it legal or contractual. If the underlying motive for the formation of a company is to enable the company's human constituent(s) to avoid their pre-existing obligation with a third party, it will give a room for piercing the corporate veil.

To this end, we can find some provisions in the Commercial Code that impose restrictive obligations on individuals. Article 158(1) of the Commercial Code provides that "the seller of business shall refrain from doing any act of competition likely to injure the buyer for a period of five years following the date of sale of the business. In particular, he may not carry on, in the vicinity of the business he sold, a trade similar to a trade carried on by the buyer." Thus, if a seller of a business establishes a closely held company or other company in which he holds a majority of shares and where this company is engaged in a competitive business which is likely to injure the buyer in the vicinity of the business he sold, the court should consider the established company as a device to evade his restrictive legal obligations.

The same applies in case of evasion of contractual obligations. An obligation validly entered into, by which one party binds him/herself not to establish a competitive business in a defined area, cannot evade the obligation by the formation of a company which is intended to run the business he/she is prohibited to establish. Article 30(2) of the Commercial Code provides that "a commercial employee and a trader may provide, in their contract of employment, a restrictive clause prohibiting the commercial employee from carrying on private trade (i.e. from entering into competitive business with his employer or engage in any way whatsoever in undertaking which would compete with the employer) upon the expiry of a contract of employment." 115 Thus, if a commercial employee establishes a closely held company or other

115 The contractual restriction imposed upon the employee is valid if and only if the work given to the employee enables him to meet the clients of the employer or enter into the secrets of his business. (Art. 2589 of the Civil Code). In other words, the restrictive agreement is valid if it is necessary for the protection of the legitimate interests of the employer. The restrictive agreement should not impede, in an inequitable manner, the economic future of the employee. To this end, the restrictive agreement should be limited as to time, place and business forbidden to the employee. (Art. 2590 of the Civil Code of Ethiopia). Moreover, the employer may not avail himself of such restrictive provision where he has cancelled the contract of employment or refuse to renew it without good cause or if it is proved that the employer has no material interest in its maintenance. (Art. 2592 of the Civil Code of Ethiopia). 
company in which he holds the majority of shares of a company engaged in a competitive business with his former employer, the court should consider the established company as a device to evade his restrictive contractual obligations.

Therefore, a person should not be allowed to evade his obligations, legal or contractual, by forming a company in which he holds a great majority of the shares or establishing a closely held share company. If he establishes a company in contravention of the restrictive obligation imposed upon him by law or by agreement, the court may recognize the existence of the corporate entity but may nevertheless pierce the corporate veil to prevent him from escaping a liability that otherwise would have been enforceable had the individual concerned not sought to hide behind the company's separate legal status. Such companies, as described above in relation with French law, should be regarded as a 'sham' or 'façade' that are utilized to evade obligations and these facts ought to justify veil piercing.

\subsection{The judicial recognition of piercing the corporate veil in Ethiopia}

This section of the article tries to assess whether the Ethiopian courts recognize and apply the doctrine of piercing the corporate veil and if so, how they apply it. Selamu Bekele argues that Ethiopian courts/tribunals cannot pierce the corporate veil and states: "in Ethiopia the law which has given legal personality to commercial companies has itself made enough holes in the veil of the legal personality so that more piercing seems unworthy of effort." ${ }^{\text {"16 }} \mathrm{He}$ further contends that:

[a]ccording to the Ethiopian ... approach, the law itself has raised the mask to a certain extent, raising beyond which appears to be contrary to a policy of a codified legal system whose aim is to ascertain the law in a code form and give little opportunity for the exercise of a judges' discretion. The wall of legal personality in Ethiopian law is built in such a manner that it is neither too strong nor too weak. If a judge wants to dig a hole through such a wall he may safely do so in regard as to what breach of duties by a director or manager of a company means. Even there, the law has set a legal standard. Finding whether a director has breached his duty, by not having due care or diligence or by not keeping the company's assets intact, is a matter of fact. As such it could not have been defined

116 Selamu Bekele(1966), Private commercial companies under Ethiopian law: their legal and practical significance, Senior Thesis, Faculty of Law, Haile Selassie I University, (unpublished), p. 22. 
any narrower as a legal principle. But that is far from letting the judge have complete discretion to collapse the wall from its foundation. ${ }^{117}$

Selamu Bekele concludes that a judge need not peep through or beyond the wall to look at the persons who may hide behind it to the prejudice of creditors. In Selamu's opinion, the role of the judge is only to look through the openings built by the legislator and this can be achieved only by ascertaining whether a director has breached his duty, by not having due care or diligence or by not keeping the company's assets intact. In effect, Selamu argues that the only statutory ground of piercing is failure of a director to act diligently and to keep the company's assets intact.

The author of this article disagrees with Selamu's view. Although Ethiopia does not belong to the common law legal system, its company law is influenced both by the common law and civil law legal systems. In the legislative background document, the drafter of Commercial Code of Ethiopia noted that "without taking into account the so called preference to be given to this or that model in the continental or Anglo American Legal system, I have always in mind the interest of Ethiopia and I have selected the solutions which I believe to be the best no matter where they come from ..."118

Even if Ethiopia belongs to the civil law legal system, it does not mean that the judges are limited and solely bound by the legal provisions of the Codes. There can be instances where the judges may have discretion to be inquisitive and flexible in the interest of justice and this reality is clear if we look at the role of judges in the court proceedings as provided in the Civil Procedure Code. ${ }^{119}$ Hirut Mellese, former Federal Supreme Court Judge, ${ }^{120}$ states that the door is not completely closed for the exercise of judicial piercing in Ethiopia at least through a broad interpretation of the available statutory holes in a way that serves justice without, however, opening a room for judicial abuse. The following decisions of courts and /or administrative tribunals substantiate this position.

Mosvold (Ethiopia) Ltd. v. The Inland Revenue Department (1965) is the first case that involved the doctrine of piercing the corporate veil in Ethiopia and it appeared few years after the enactment of the Commercial Code. The case was

${ }^{117}$ Ibid, pp. 22.

118 Winiship P. (1972), (Editor and Translator), Background Document of Ethiopian Commercial Code of 1960, Faculty of Law, Haile Selassie I University, (Addis Ababa: Artistic Printers), p. 61.

119 Interview with Ato Asrat Eshetu, Assistant judge at the Federal High Court, conducted on May 17, 2011.

${ }^{120}$ Interview with W/ro. Hirut Melesse, former Federal Supreme Court Judge, conducted in may $25 / 2011$. 
first seen by the Tax Appeal Commission (an administrative tribunal), as Mosvold (Ethiopia) Ltd. v. The Inland Revenue Department, File No. 1130/56, on appeal against the income tax assessment by the Inland Revenue Department which treated the appellant company and a related company (Mosvold Wood Works Ltd.) as single entity for income tax purposes. ${ }^{121}$ The argument of the appellant was that the two companies (i.e. Mosvold (Ethiopia) Ltd. and Mosvold Wood Works Ltd.) are separate and distinct legal entities validly formed by separate Memorandum of Association and registered in the Commercial Register; that they have different business purposes since one is engaged in commercial activities while the other is engaged in manufacturing (industry); that there is no law enabling the revenue department to consider the two entities as if one is the main office and the other a branch; and that they are separately registered in the Ministry of Commerce and Industry. The appellant argued that, the Inland Revenue Department erred in considering them as a single entity for income tax purposes. ${ }^{122}$

The counsel for the Inland Revenue Department, on his part, replied that the two companies are registered separately for tax avoidance purposes; that their activities are related and Mosvold (Ethiopia) Ltd. gets all the benefits, and Mosvold wood works is owned exclusively by Mosvold (Ethiopia) Ltd. and its shareholders. Hence, he argued that their income must not be treated separately and the consolidation of the book of accounts of the two entities is proper. ${ }^{123}$

The Tax Appeal Commission, after hearing the arguments of both parties, held that the two companies should be treated as a single entity for tax purposes. The tribunal reasoned that, even if the two companies were registered separately, the shareholders in the first company are exclusively the founders of the second company; that the two companies undertake sale transactions jointly and also share the profits, and it appears that the second company was formed in order to reduce the income tax liability of the enterprises as a whole. Therefore, the Commission, by majority vote, decided that the incomes of the two companies shall have to be consolidated for purposes of levying the income tax notwithstanding the fact that they are organized as separate companies under the Commercial Code. ${ }^{124}$ The decision of the Tax Appeal Commission was similar

${ }^{121}$ In principle, every member of a group companies is with its distinct personality which is followed by limited liability. Thus, in tax laws, each member of a group bears its own tax burdens on the basis of all the profits it has earned, irrespective of the loss and profits the other group may have incurred.

${ }^{122}$ Mosvold (Ethiopia) Ltd. V. The Inland Revenue Department (Tax appeal Commission, 1965), Journal of Ethiopian Law, Vol. 4, No. 1, p. 122.

${ }^{123}$ Ibid.

${ }^{124}$ Ibid, p. 123. 
to the common law doctrine of piercing the corporate veil on the ground of establishing a single economic entity.

Although the Tax Appeal Commission did not invoke Article 451(1) of the Commercial Code, the provision states that " $[\mathrm{w}]$ here a company is a holding company, the accounts of its subsidiaries shall be submitted to the annual general meeting at the same time and in the same manner as its own accounts". ${ }^{125}$ Article 451(2) further provides that "[a] consolidated balance sheet and profit and loss account shall be prepared in respect of the holding company and its subsidiaries". ${ }^{126}$ The only exceptions to this rule are where the directors believe that "the drawing up of such balance sheet would be impractical or too onerous, or of little concern to the shareholders on account of the small financial interests involved"; 127 or "where the directors of a holding company are of opinion that the drawing up of such balance sheet could prejudice the company or its subsidiaries, or that the company and its shareholders carry out business of such a differing nature that they may not reasonably be deemed to form a single enterprise", and if this opinion is approved by the Ministry of Commerce and Industry. ${ }^{128}$ As the facts of the case shows, the two companies (i.e. Mosvold (Ethiopia) Ltd. and Mosvold Wood Works Ltd.) are engaged in activities of related nature. The case shows that companies established with a view of evading or minimizing tax may be considered (by courts and tribunals) as a single entity for tax purpose, ${ }^{129}$ as an exception to the rule of distinct legal personality.

${ }^{125}$ Commercial Code, supra note 17, Art. 451(1).

${ }^{126}$ Ibid, Art. 451(2).

${ }^{127}$ Ibid, Art. 451(3).

${ }^{128}$ Ibid, Art. 451(4).

${ }^{129}$ Some commentators argue that treating a group as a single entity is more advantageous for that group in case of tax. They argue that if a group is considered as a single entity, the losses that the other group members have incurred will be deducted from the profits of one group member whenever taxable profits are calculated which ultimately reduces the taxable income. Moreover, it has also the advantage of avoiding tax charges on gains from intra-group transactions. For example, if one group member acquires certain assets from another group member, the gains of the seller company do not trigger a tax charge as the transaction is considered to be undertaken within a single entity. (See Belayneh Ketsela, the need for the regulation of group Companies in Ethiopia, pp.21-22 cited above, note 110). However, the above argument will have merit only when the group of companies incurs losses. But, if the groups of companies are profitable, the sum of profits will be higher thereby increasing the tax liability. 
However, an appeal was lodged to the High Court against the decision of the Tax Appeal Commission (Mosvold (Ethiopia) Ltd. v. The Inland Revenue Department, file No.820/58), ${ }^{130}$ The High Court reversed the decision of the Tax Appeal Commission arguing that companies organized separately under the Commercial Code are to be treated as separate entities for tax purposes. It further argued that the intention of the legislator is not to hold such companies as one legal entity for tax purposes. If the contrary was the intention of the legislator, it would have addressed such cases in the tax law itself. ${ }^{131}$

The High Court simply decided that the two companies, registered separately in the Commercial Register, are two distinct bodies and entities without further inquiring into other circumstances to see whether Mosvold Wood Works was, in fact, a subsidiary established for tax avoidance or other improper purposes. In particular, the shareholding in the two companies must have been considered. The shareholders in Mosvold Wood Works were four. Out of the 300 shares 294 of them were held by the appellant, Mosvold Company. The remaining six shares were equally held by three persons who were also shareholders in the appellant company. ${ }^{132}$ The Court should have also considered how the business of the Mosvold Wood works was being conducted. That is, the fact that both companies undertake related activities in which the appellant was engaged in furniture selling business, and that the second company provided it with the necessary woodwork products. Hence, the decision of the court reversing the decision of the Tax Appeal Commission failed to consider these realities.

A recent case related to the doctrine of piercing the corporate veil, Feven Zemen et al v. Askalukan Trading PLC and Others ${ }^{133}$ involved 42 persons ${ }^{134}$ as plaintiffs while the defendants are Askalukan Trading PLC, Ato Girmaye G/Michael (A director for the PLC), W/ro. Mena Terefe (A manager for the PLC), and Ato Girma Bekele (An accountant for the PLC). Askalukan Trading PLC made announcements through different Media (newspapers, radio, TV, notices etc.) that it is the only organization that arranges a travel to South Africa for the 2010 World Cup events. Hence, the plaintiffs concluded a contract with the Askalukan Trading PLC in which the company undertook to arrange travel

${ }^{130}$ Mosvold (Ethiopia) Ltd. v. The Inland Revenue Department (High court, 1967), J.Eth. L., Vol. 4, No. 1, p. 104.

${ }^{131}$ Ibid, p. 105 .

${ }^{132}$ Seifu Tekle Mariam, supra note 3, p.28.

${ }^{133}$ W/rt. Feven Zemen and Others v. Askaluka Trading PLC and Others, (Federal High court, Civil File No. 96230, 2003 E.C), Unpublished.

${ }^{134}$ It is in this file No. 96230 that the plaintiffs are only 42 . The defendants are sued by other persons in many separate civil files. The defendants are also charged under a separate criminal case. However, this civil file is chosen for the purpose of the discussion on the doctrine of piercing the corporate veil. 
to South Africa to enable them attend the 2010 World Cup events. To this end, the PLC collected Birr 37,582.65 from each of the 40 plaintiffs, Birr 47,632.06 and Birr 48,333.67 from two plaintiffs whose travel tickets were expected to be used with a child. The total amount of Birr 1,599,217.06 was collected from the 42 plaintiffs. However, the company was unable to discharge its duties or return the money to the plaintiffs. ${ }^{135}$

Even though summons was sent to the defendants to appear on the date fixed for the hearing, they were not able to appear except for the fourth defendant (Ato Girma Bekele). The court then, ruled to hear the case in their absence (ex parte). The fourth defendant, at the hearing, argued that he is a mere employee (an accountant) of the company and was not involved in the affairs of management. He further argued that he should not be responsible because the company has its own legal personality and the contract was concluded between the plaintiffs and the company itself. ${ }^{136}$ After hearing his oral argument and the evidence presented to it, the Court dismissed the claims against the fourth defendant on the ground that he is a mere employee of the PLC and stated that the fourth defendant has no contractual relationship with the plaintiffs and that he is neither a member nor a director or manager of the PLC. ${ }^{137}$ However, the court decided that the company (Askalukan PLC), the director (Ato Girmay G/Michael), and the manager (W/ro. Mena Terefe) are jointly and severally liable for the claims of the plaintiffs and shall pay the debt together with legal interest rate (i.e. $9 \%$ per annum). ${ }^{138}$

The High Court stated that the director and manager did such illegal or fraudulent activities on the assumption that they will not be personally responsible for any act of the company as the latter has its own separate legal personality and that they were shielded by the advantage of limited liability. ${ }^{139}$ However, the court reasoned that, the limited liability advantage exists only if the member(s), director, and manager use the company for lawful purposes. It then underlined that there is no reason why the liability of the company cannot be extended (shifted) to the director and manager if they employ it for fraudulent or illegal purposes. ${ }^{140}$

\footnotetext{
${ }^{135}$ The statement of claim of the plaintiffs prepared and submitted to the Federal High Court in June 28/2002 E.C.

${ }^{136}$ W/rt. Feven Zemen and Others v. Askaluka Trading PLC and Others, supra note 133, p. 3.

${ }^{137} \mathrm{Ibid}$, the decision part, p. 6.

${ }^{138}$ Ibid.

${ }^{139}$ Ibid, p. 5

${ }^{140}$ Ibid.
} 
In the case at hand, Askalukan Trading Private Limited Company was formed by two persons, who are spouses and who are exclusive shareholders at the same time having the functions of director and manager of the company. Their personal assets and the assets of the company are thus susceptible to be intermingled which makes it very easy to shift the assets of the company to their own personal benefits.

Therefore, the Federal High Court rightly pierced the corporate veil of the Askalukan Trading PLC and decided the members, who were the director and manager of the company as well, jointly and severally liable with the PLC for the claims of the creditors. The Court observed that the limited liability advantage shall not apply if the members, director (s) and manager (s) use a company for fraudulent purposes, in which case the company is regarded as a device or legal façade.

Needless-to-say, the two cases highlighted above do not fully represent the jurisprudence of Ethiopian courts. Yet, they offer examples and thresholds regarding what can be done by Ethiopian courts in the implementation of the doctrine of piercing the corporate veil, a role which requires not only the literal interpretation of the statutory provisions, but also a wider flexible and purposive interpretation commensurate with the magnitude of abuse that can unfold.

\section{Conclusion}

The legal personality of companies (as separate and distinct from its shareholders) and limited liability are recognized under Ethiopian law thereby rendering shareholders liable only to the extent of their shareholdings as stated under Articles 304 and 510 of the Commercial Code. This veil is a partition or curtain between the company and its members and is regarded as a privilege for the shareholders as it covers them in the corporate veil and keeps them from the reach of outsiders (creditors). However, such privilege of limited liability may not always exist in certain circumstances as discussed in the preceding sections owing to the possibility of piercing the veil of a company.

Although there is no consistent guiding principle to govern the circumstances in which a court should pierce the corporate veil, common law courts cite some basic grounds which include the fraud exception, the establishment of a single economic entity, the ground of agency and the interest of justice. Likewise, there are some grounds of statutory and judicial piercing in the French legal system.

The Commercial Code of Ethiopia has also provided some clear statutory solutions to the most important aspects of piercing the corporate veil. However, the statutory grounds of piercing the corporate veil under Ethiopian law, as highlighted above, are limited. Since Ethiopia is on the eve of enacting a new Commercial Code, the legislative reform should thus consider this problem and 
provide additional grounds for piercing the corporate veil. Particularly, as the new (draft) Commercial Code recognizes and introduces a one man company into the Ethiopian legal system, it is necessary to provide sufficient rules that can regulate the possible abuses of the sole owner.

Moreover, the preceding sections have highlighted other possible (ought to be) grounds for piercing the corporate veil in Ethiopia on top of the clearly provided statutory grounds. These possible grounds include: reduction of members of a private limited company below the required legal minimum, the case of trade restraint where a person establishes a company to evade obligations, legal or contractual, and the case of sister companies if there is no substantive separation as between themselves.

Ethiopian Courts are not proactive enough in applying the doctrine of piercing the corporate veil although some attempts are made to that effect, as shown above. This seems to be attributable to the perception that Ethiopia is following a codified legal system and the only role of the judges is to ascertain the law as embodied in the Codes. However, the Ethiopian company law is influenced by both the common and civil law legal systems. Moreover, following a civil law legal system does not necessarily mean that the judges are limited and solely bound by the legal provision of the Code. Thus they have the discretion to be inquisitive and flexible in the interest of justice whenever there are gaps in the law that are conducive to business malpractice and abuse in the guise of the corporate veil. In particular, the Cassation Division of the Federal Supreme Court is expected to play a vital role in this regard as it is empowered to give decisions on cases which have a fundamental error of law and which ultimately serve as a precedent with regard to the interpretation of similar legal issues. 